\section{Stimulation of Neuron Proliferation by Means of Growth Hormone}

IN further investigation of the theory I have already outlined ${ }^{1,2}$ that by means of the growth hormone preparation it may be possible to stimulate artificially the proliferation of prospective cerebral neurons in mammals, I have used 385 albino rats in an attempt to improve the level of the psychical functions of the animal.

The rats were subjected in pregnancy to subcutaneous injections of growth hormone preparation 'Antuitrin G' and 'Phyone'. 'The offspring investigated at birth showed an increase of 18.7 per cent in body weight, 36 per cent in cerebral hemispheres weight, 21 per cent in thickness of the cerebral cortex, 70.4 per cent in volume of the cortex, $9 \cdot 27$ per cent in density of cells, and 86.5 per cent in number of cells per volume of cortex, as compared with the controls. All these increases are statistically significant.

A certain number of animals reached maturity, and proved to show an increase of $14 \cdot 8-27 \cdot 6$ per cent in cell density, and 38-40.6 per cent in total number of cortical neurons, as compared with the controls. These increases are statistically significant.

It is concluded that in mammals the growth hormone preparation administrated in pregnancy does increase the number of cortical neurons in the offspring.

A full report on this work will be published elsewhere.

S. ZAMENHOF.

Work done in the Dept. of Animal Care,

School of Physicians and Surgeons, Columbia University, New York City.

'Zamenhof, S., “On Present Possibilities of Increasing the Higher Functions the Cortex Through Artificial Changes in Its A rehitectonic,", The Science Press Printing Co., Lancaster, 1940. ${ }^{2}$ Zamenhof, s., Growth, 5 (June, 1941).

\section{The Hamburgh Parsley}

The Hamburgh parsley, known also as the largerooted parsley, turnip-rooted parsley or parsniprooted parsley, has been developed on the Continent for its root instead of the usual leaves. It is a vegetable which deserves much wider use in Great Britain both for its pleasant flavour, which most nearly resembles celeriac, and as a particularly rich source of vitamin $\mathrm{C}$ during the winter months.

There are two varieties, the late, with long thin roots, and the early, which forms a compact root like a short thick parsnip. The latter is the more useful type and is the form on which these notes are based. At Cambridge stocks have been grown from Danish, French and German seed, the Danish producing the best-shaped roots. The roots are a very pale yellow colour, almost white, and they form an excellent vegetable either boiled, used in vegetable stew or soup, or grated and eaten raw.

Cultivation is the same as for parsnips, but the roots are easier to dig and remain free from canker. From a sowing made on April 18, usable roots were obtained in October and remained in good condition when stored until the end of the following April. The roots appear to be unaffected by frost and can be left in the ground and dug as required for use, or can be stored in a clamp. No figures for the rate of cropping have been obtained, but it should be reasonably high judging by the appearance of roots lifted from observation rows. The Hamburgh parsley will grow on poor soil, having thrived on the hot dry gravel at Cambridge.

The greatest merit of this vegetable as a war-time crop is its rich content of vitamin $\mathrm{C}$ which is available during the winter months. It has been found by a nutritional laboratory that roots which had been stored for 5 months still contained about $21 \mathrm{mgm}$. of vitamin C per $100 \mathrm{gm}$., a much higher value than is known in any root vegetable except swedes.

Horticultural Research Station,

S. DARK.

The University,

Cambridge.

\section{Plankton as a Source of Food}

MANY will have read with interest the recent proposals $^{1}$ concerning the possible use of plankton for human or livestock food. There is, however, an entirely different aspect of the subject which ought to be considered and would at least in one connexion be of far easier application. I refer to the possible use of plankton-especially freshwater phytoplankton -for plant nutrition, and the 'connexion' is the small vegetable gardener who has to water his plants. 'If he does this repeatedly or at least frequently in what is often the easiest way, namely, from open tanks or pans or from the A.R.P. buckets we are supposed to have outside our doors, he may be adding a very useful amount of nutrient matter to the soil, at least during periods of plankton 'maximum'. In hot sunny weather, just when watering is most necessary, great algal activity (which may turn water green in a day) may be maintained week after week and used almost nightly by merely leaving the green or brownish investment on the inside of the vessel intact when fresh water is added.

It seems probable that in these present times when farmyard manure is often impossible to obtain, such frequent planktonic additions, the component individuals of which often go on growing and dividing on or below the surface of the soil but ultimately will be washed down and decomposed, would go at least some way towards remedying the deficiency-without extra trouble or expense to the gardener. Only a sunny situation and wide open vessels are necessary, and sometimes the addition of a nitrogenous and phosphatogenous solution (for example, a very few drops of liquid manure).

It has been my intention for some months past to experiment along these lines and find out if the suggested benefit is really considerable, especially under other than optimal conditions; but as I have as yet had no opportunity to do this with proper controls, and am unlikely this year to have the time even to read all the pertinent literature ${ }^{2}$, I record these ideas and intentions in the hope that they may be taken up and made use of by someone else. Other, connected possibilities which have come to mind, but about which I can find no published ad hoc research, I would gladly impart to or discuss with any responsible person who may be interested.

The Herbarium, Nicholas Polunin.

Department of Botany,

University of Oxford. July 23.

The Times, May 6, 1941, and NATURE, 147, 695, 808 (1941). ${ }^{2}$ Useful bibliographies are given in $J$. Ecology, 19, 266 (1931) and 28, 491 (1940); see also Ann. App. Biol., 26, 165 (1939). 